\title{
Tamang Heritage Trail:A Study of Gatlang Village in Rasuwa District of Nepal
}

\author{
Ramesh Raj Kunwar* \\ Chadani Pandey**
}

\begin{abstract}
Tourism can be viewed as a space-time convergence between hosts and guests. The emergence of ethnic and cultural tourism implies that tourism also includes interaction and encounter between hosts and guests. Ethnic tourism provides opportunities to ethnic minorities to showcase their culture, customs and heritage. The unexplored soil of Tamang village was opened to bring them into the mainstream of development through propoor approach. When tourism is introduced culture is commoditised. Regarding this matter, the scholars are divided into two camps. Accordingly, one school of thought clearly advocates that tourism brings cultural transformation whereas the other camp proposes that commoditisation will not affect on the culture of host population. The economic and sociocultural impacts of tourism is dealt along with the income generation and change in gender roles. In this study, Tamang Heritage Trail as an academic subject includes tourism and ethnicity, cultural heritage tourism, tangible and intangible heritage, niche-tourism, adventure tourism ,cultural resource management and homestay. This study follows culture as multi-variate concept and tourism is composite discipline.
\end{abstract}

Key words: ethno-cultural-heritage tourism, authenticity, commoditization, touristic attractions, homestay

The Tamang Heritage Trail (THT) and Tamang Heritage Trek denotes the community, heritage, space/place, and performances. On one side, there comes ethnicity in relation with with the Tamang ethnicity and the other the title itself indicates that it is heritage tourism. Therefore, it is ethno-cultural heritage tourism. As far as the area is concerned, people will visit over there to undertake trekking as

\footnotetext{
* Prof. Dr. Ramesh Raj Kunwar is the author of seven books on tourism and anthropology. He is tourism educationist and anthropologist by profession. He is the former Dean of Faculty of Humanities and Social Sciences, Tribhuvan University, Kathmandu, Nepal. He is also the former Dean of (then) Royal Nepalese Military Academy. Currently, he is teaching at the Central Department of Culture, Kirtipur Campus, T.U. Email: kunwardr@gmail.com

** Chadani Pandey is a Lecturer and Deputy Research Co-ordinator at King's College, Kathmandu. She is M.A. in Conflict, Peace and Development Studies from Tribhuvan University, Kathmandu, Nepal.
} 
an activity which has been used the term as 'romantic gaze' (Urry, 2002). Doing trekking in the mountain falls into the category of adventure tourism. Adventure tourism in the context of Nepal Himalayan region incorporates different forms of tourism such as cultural tourism, heritage tourism (also called cultural heritage tourism), religious or pilgrimage tourism, rural tourism, village tourism, eco-tourism and home stay tourism (although it is a kind of accommodation that comes within the category of hospitality). All these forms of tourism have their own nature, scope, and meaning. But in the context of Rasuwa, they could be interchangeably used. Theoretically, cultural tourism is recognized as macro-niche whereas the other types of tourism fall into micro-niche representing the specific types of tourist who will be motivated differently. In the same way, the place is commoditized according to the demand of specific group of people whose interest particularly focus on the special product.Sometimes the term 'niche tourism' is used instead of special interest tourism (e.g. Novelli, 2005; in Smith, Macleod and Hart Robertson, 2010, p.161). In his foreword to the book, Robinson (p.xx) describes niche tourism as:

an economy of imagination where individual preferences and practices are coordinated, packaged, and sold. The wants and wishes of the bird watcher, the golfer, the genealogist, the railway enthusiast, can be purchased; indeed, the fullest stretches of the imagination can be catered for.

Novelli (2005; in Smith et.al, 2010, p.161) suggests that the development of niche products is a part of a wider structural process of diversification as the tourism industry seeks to capture new and more profitable markets. In terms of product characteristics and tourist motivations, special interest tourism could be described as passive (performances, spectator sports), active (adventure sports, diving), experiential (theme parks, space tourism), adventurous (jungle trekking, tribal visits), creative (dance, painting, photography), intellectual (language-learning, heritage tourism), or relaxing (wellness tourism, bird watching.

Though the Tamang Heritage Trail as a project is new innovation to Nepal's Himalayan region, particularly in Rasuwa, popularly known as Langtang trekking destination, excluding the studied areas, the heritage trail as a concept is not new because some other tourist destinations have already introduced this concept which has been cited by S.C.H. Cheung in 1999. His work is entitled 'The Meanings of the Heritage Trail in Hong Kong' published in Annals of Tourism Research, 26 (3) (pp.570588). Similarly, Polly Patullo who has written one paper entitled' Reclaiming the Heritage Trail: Culture and Identity' based on Caribbian - Jamaica's Heritage Trail published in 2006 in a book entitled Sustainable Tourism (pp.135-148) edited by Lesley France, First South Indian Edition.

Heritage tourism supply includes both intangible and tangible elements of the past that form and constitute tourism products and services. Intangible heritage and tangible heritage are often viewed as two separate realms of heritage representing 'pre- 
modern and vernacular' and 'modern and authoritative' respectively. However, it is critical to recognise the deep-rooted interdependence between intangible heritage and tangible heritage. Memory, cultural knowledge and performance are grounded and embedded in tangible heritage derives from its cultural and symbolic significance. (Park, 2014, p. 206). Intangible heritage in this context is related to evoking the spiritual and the symbolic aspects of sites or places. Tangible aspects of heritage provide symbolic foundations where intangible qualities prevail (p.207).

As noted above, the nature of trekking in Tamang Heritage Trail and LantangGoshaikunda- Helambu trek is adventurous activities and therefore, it is adventure tourisim. The influence of adventure recreation theory as indicated in Hall's (1992, p. 143; in Kane and Tucker, 2004, p. 220) statement that adventure tourism is a commercial activity 'categorized by the deliberate seeking of risk and danger'. He defined adventure tourism as: "A broad spectrum of outdoor touristic activities, often commercialized and involving an interaction with the natural environment away from the participant's home range containing element of risk; in which the outcome is influenced by the participant, setting, and management of the touristic experience" (1992, p. 143). Adventure tourists can be divided into those participating in hard or soft adventure, which Millington (2001; in Swarbrooke et al., 2003:104-105) has defined : "Hard adventure travel requires an element of experience in the activity being undertaken, and because it encompasses an element of risk, participants must be physically and mentally fit. It includes an intimate experience with the environment and culture of the destination. Participants should be prepared for all weather conditions, sleeping arrangements and dietary restrictions. Examples includes: Climbing expeditions, arduous treks, hang gliding, rock climbing, white- water kayaking and Wilderness survival".

The visual display of people, places, and things makes them forms of "spectacle" and tourism involves the "spectaclization of place" (Urry, 1992a, p.5; in Knudsen, Soper, and Metro-Roland, 2008,p.3). Urry's reframing tourist sites as "spectacles of place" wherein the object of the gaze is typically an artful construction of signs (Midtgard, 2003;in Knudsen et al., 2008,p.3). If tourism is spectacle, then surely there are multiple parties involved in the creation of this spectacle (Squire, 1994; in Knudsen et al., 2008, p.4). In this regard, Nash suggests that tourism should generally be understood as a discourse among three sets of actors: i) tourists; ii) locals; iii) intermediaries, including government ministries, travel agents and tourism promotion boards (1996; in Knudsen et al., 2008, p.4). Davis (2001, p.127;in Knudsen et al., 2008, p.5) notes "histories, cultures, power relations, aesthetics and economics all combine at a place to create a context ". It is simultaneously nature, habitat, artifact, system, problem, wealth, ideology, history, pace and aesthetic (Meinig, 1979; in Knudsen et al., 2008, p.5). Tourist objects and places (that is to say landscapes) have local, endemic, insider meanings, and broader pandemic outsider meanings (Lowenthal and Price, 
1972 in Knudsen et al., 2008, p.5). The landscape is an illusive term that is commonly associated with attractive scenery. In his seminal work, place and placelessness, Relph (1976) argued that the concept of sense of place was most applicable in the local environment, where individuals are in a position to develop deep attachments to the place. Hinch and Higham, 2006, p.100; in Kunwar, 2013, p.23.

"Seasonality is defined as a temporal imbalance in the phenomenon of tourism, which may be expressed in terms of dimensions of such elements as numbers of visitors, expenditure of visitors, traffic on highways and the other forms of transportation, employment and admissions to attractions"(Butler, 2001; Hinch and Higham, 2006, p.163; in Kunwar, 2013, p.23) Tourism by definition takes place in a tourism landscape (Knudsen et al., 2008, p.5).

Research suggests that, in most cases, people visit heritage places to enhance learning, satisfy curiosity and feelings of nostalgia, grow spiritually, relax, get away from home, spend time with loved ones, or "discover themselves" (Confer and Kerstetter, 2000; Krakover and Cohen, 2001; Porai et al., 2004; Prentice et al., 1997; Timothy, 1997; Timothy and Boyd, 2003; in Timothy and Nyaupane, 2009, p.8). One recent study (Nyaupane et al., 2006) classified heritage tourists into three types based upon motivations, combined with relics from the past, create a range of heritage tourism types.Smith accepts a broad definition of culture that embraces "almost any activity that relates to the lives and the lifestyle of human beings" (2009, p.2). Living culture is an important part of heritage tourism in the less-developed world. Agricultural landscapes, agrarian lifestyles, arts and handicrafts, villages, languages, musical traditions, spiritual and religious practices, and other elements of the cultural landscape provide much of the appeal fro tourism in Less Developed Countries (LDCs). Rice paddies and farming techniques, traditional architecture and building materials, intricate clothing and cloth, exotic-sounding music, vibrant ceremonies, and unusual fragrances and flavors are the part of the appeal (Cohen, 2001; Gibson and Connell, 2005; Hall et al., 2003 Howard, 2004; Volkman, 1990). Often, cultural festivals develop that are based on spiritual traditions, agricultural harvests, or other constituents of culture (Coulon, 1999; Hitchcock and Nuryanti, 2000; Swearer, 1995; in Timothy and Nyaupane, 2009, p.9)

Ethnicity can be defined as "the existence of culturally distinctive groups within a society, each asserting a unique identity on the basis of a shared tradition and distinguishing social markers such as common language, religion or economic specialization" (Winthrop, 1991, p.94). Though the term ethnicity is vague, it denotes a socially distinct group of people having a common culture, history and language. According to Weiler and Hall (1992, p.84; in Xie,2001), ethnic tourism "entails some form of first-hand, face-to-face experience with local people, either by visiting their land or observing or participating in local customs, rituals and other traditional activities". 
Ethnic tourism thus involves first hand-on experience with ethnic communities. It refers to a kind of tourism where indigenous people or ethnic communities and their cultures are the main attracting points for tourism, and tourists get chance to interact directly with indigenous people (Weiler, 1984). In relation with this definition, Nepal can offer plenty of chances to tourists to engage with ethnic communities through various ways. In this case, home-stay tourism can help promote ethnic tourism.

Nepal is a multi-racial, multi-cultural, multi-religious and multi-lingual country. Nepal is the homeland to a wide range of various ethnic /caste groups. There are four racial groups, 125 ethnic/caste groups, 123 dialects and 10 religions in Nepal (Central Bureau of Statistics, 2011). Geographically, the northern region of Nepal is called the Mountain region. This region is inhabited by the Lhomis, Sherpas, Yolmowas, Langtange, Shyars, Nubris, Neyshyangwas, Narwas, Gyasumdowas, Lopas, Mugalis, Dolpowas and Nymbas (Kunwar, 2010, p.321). These people follow Tibetan-Buddhism and shamanism, and speak Tibeto-Burmese language. Similarly, the hilly region is inhabited by the Gurungs, Rais, Limbus, Brahmins, Chhetris, Newars, Tamangs, Thakalis, Chepangs, Damais, Kamis, Sarkis, Rautes, Kusundas, Magars, Gaines, Chhyantyals and so on (Kunwar, 2010, pp.321-322). Basically the caste groups such as Brahmin, Chhetris, Thakuris speak Indo-Aryan language whereas the others like Gurungs, Tamangs, Magars speak Tibeto-Burmese language.The southernmost Terai region, has been inhabited by the Kisans, Tharus, Darais, Majhis, Botes, Rajis, Madhesis, Dhimals, Satars, Rajbansis, Jhangads, Muslims and hill migrants (Kunwar, 2010, p. 322). These various caste and ethnic groups have their own cultures and lifestyles and hence make Nepal a diverse array of ethnic/caste groups and cultures. Hence, Nepal is rich in ethnic and cultural diversities, and, therefore, Nepal has plethora of scope and opportunities to promote ethnic tourism.

Tamang Heritage Trail (THT), Rasuwa was introduced by the Government of $\operatorname{Nepal}(\mathrm{GoN})$ as a part of Tourism for Rural Poverty Alleviation Program (TRPAP). Rasuwa is situated north of Kathmandu which is approximately $124 \mathrm{~km}$ far from the capital. Everyday there is bus service from Kathmandu to Syabrubesi little far from Dhunche, the starting point of trekking to Langtang and Tamang heritage trek. The Tamang heritage trail is a completely new eight-day trail that passes through backward but culturally rich villages of Goljung, Gatlang, Chilime, Tatopani, Brimdang, Nagthali, Thuman, Timure, Briddhim and Syabrubesi (TRPAP, 2007, p.37) and inhabited by the Tamangs, one of the ethnic groups of Nepal, whose dense settelement is found in Dhading, Nuwakot, Rasuwa, Kavrepalanchowk, Sindhupalchowk and in the northern part of Kathmandu.

The Tamangs are considered as one of the indigenous communities of hilly region who live in between 5,000-7,000 ft high above the sea level. The indigenous societies are what ethnobiologist Gary Paul Nabham terms "cultures of habitat". They are "human communities that have a long history of interaction with a particular kind 
of terrain and its wildlife" (Nabhan, 1997,p.3; in Willow, 2011, p.116). Because the natural resources used by indigenous people today are often the same as those used by generations of ancestors indigenous communities tend to misuse these resources with a high degree of cultural significance.The Tamangs have close attachment with their natural setting. Urry(1995, p.174; in Jamal, Everett and Dann, 2003, p.144) summarises four ways in which society relate to their physical environment: stewardship (of the land for future generations), exploitation(of the land or other resources), scientization ( of the land as an object of scientific investigation, intervention and the regulation), and visual consumption(of the landscape/townscape and aesthetic appreciation).

This research aims to sketch the characteristics of Tamangs in Gatlang after the initiatives of TRPAP. The home-stay facilities available in THT provide opportunities to experience the cultural and ethnic richness of these villages. However, there are hotels and lodges to provide hospitable services with the compromise in ethnographic authentic cultures.

\section{TRPAP : A Model Tourism in Tamang Heritage Trail}

With the concerted efforts made by TRPAP during its over five year's period, Nepal was able to demonstrate community based sustainable rural tourism models to reduce rampant rural poverty. TRPAP enabled the country to diversify tourism products. As a result, there were seven different tourism models developed in its six districts. Piloting new pro-poor sustainable tourism products in rural areas was envisaged as a major activity in the TRPAP design. The mid-term evaluation directed TRPAP to put more private sector focus, small business emphasis, and tourism marketing effort into the creation of these models. Subsequently, the TRPAP developed and promoted a range of new tourism products(TRPAP, 2007).

Heritage can be classified into two types: cultural heritage and natural heritage Cultural heritage is composed of: Monuments: architectural works, works of monumental sculpture and painting, elements or structures of an archaeological nature, inscriptions, cave dwellings and combinations of features, which are of outstanding universal value from the point of view of history, art or science. Groups of buildings: groups of separate or connected buildings that, because of their architecture, their homogeneity or their place in the landscape, are of outstanding universal value from the point of view of history, art or a science. Sites: works of man or the combined works of nature and man, and areas including archaeological sites that are of outstanding universal value from the historical, aesthetic, ethnological or anthropological point of view.

The following is considered as 'natural heritage':

- Natural features consisting of physical and biological formations or groups of such formations, which are of outstanding universal value from an aesthetic or scientific point of view. 
- Geological and physiographical formations and precisely delineated areas that constitute the habitat of threatened species of animals and plants of outstanding universal value from the point of view of science or conversation.

- Natural sites or precisely delineated natural areas of outstanding universal value from the point of view of science, conservation or natural beauty.

TRPAP introduced a completely new eight-day trail passing through the backward but culturally rich villages of Goljung (1946m), Gatlang (2238m), Chilime (1762m), Tatopani (2607m), Brimdang (2848m) Nagthali (3165m), Thuman (2338m), Timure (1762m), Briddhim (2230m) and Syabrubesi (1460m) (TRPAP, 2007). This trail features Tamang culture, religious sites at Parvati Kunda (lake) and Tatopani(Hot Spring), magnificent Himalayan views from Nagthali meadow hilltop, and historical fort of Rasuwa Gadhi bordering Tibet. Lodges and home stays were developed in the villages along the route, and Gatlang now has accommodation in its community lodge and cultural centre. A relatively easy, soft trekking product, the trail contains Buddhist chortens, monasteries, traditional mountain villages, interesting architecture, crafts and customs, exquisite landscapes and a natural hot spring. The Tamang Heritage Trail offers authentic cultural performances and ethno-botanical and cultural features. Its promotion has helped tourism benefits to many excluded communities in the area (TRPAP, 2007).

The title of the trek indicates "Tamang Heritage Trekking” is a cultural trekking program along the ancestral 'Tamang' villages in Langtang region with beautiful scenery and Himalayan vistas. Thus, developed pristine area offers enchanting journey to experience the rich culture and lifestyle of the Tamangs. Previously restricted area for traveler near to the Tibetan border; within the Langtang National Park is now developed as Tamang Heritage trail. The region is mostly populated by the Tamangs and people from Tibetan origin, whose culture and traditions are more likely to Tibetan Buddhist influence. Their cultural aspects, traditional way of living, crafted dresses, traditional wooden roofed houses,cultural performances are authentic experience for tourists.

Tamang Heritage Trek presents the views of several silver capped mountains including Langtang Lirung, Langtang Kerung, Dorje Lakpa, Ganesh Himal, Shringi Himal, Jugal Himal with warm Tamang hospitality (see in detail March, 1987, pp.351357) in traditional way. The people-oriented approach has resulted in alternative livelihoods capacity building, skills training, increased agricultural productivity, employment opportunities, empowerment, and the improved ability to combat poverty.The small-scale tourism infrastructure such as the construction of trails, bridges, signposts, information centres, public (porter) shelters, improved water, sanitation, waste disposal and renewable energy projects were introduced. It has achieved successful micro finance projects, social mobilisation and institutional enhancement. A sense of local ownership has prevailed through the formation of institutions with community representation. This led to better development and mnagement of processes, and eventually resulted in better outcomes. 
The trail has been developed and promoted by Tourism for Rural Poverty Alleviation Programme (TRPAP) through the District Development Committee (DDC) Rasuwa since 2002. The trail starts from Syabrubesi, passes through Goljung, Gatlang, Chilime, Thuman, Timure and ends at Briddim. Efforts have been made to develop tourism in Tamang Heritage Trail based on four pros like Pro-Environment, Pro-Community, Pro-Poor and Pro-Women (TRPAP, 2007). In this regard, TRPAP successfully (TRPAP, 2007) introduced tourism products to new areas and new communities, with special efforts to target women and deprived groups through different trainings and awareness programs. Even in established tourism destinations, TRPAP sought to spread tourism benefits to new and more remote areas. For example, in Solukhumbu,efforts focused on new products in the more neglected parts of the district, leveraging off the strong tourism flows on the Everest route. In Langtang, the third most popular trekking area, the Programme developed a completely new circuit trail.

Table-1: Major touristic attractions of the THT

\begin{tabular}{|l|l|l|l|}
\hline VDCs & \multicolumn{1}{|c|}{ Cultural Resources } & \multicolumn{1}{|c|}{ Natural Resources } & \multicolumn{1}{|c|}{$\begin{array}{c}\text { Historical } \\
\text { Resources }\end{array}$} \\
\hline Goljung & $\begin{array}{l}\text { Tamang culture, Syabru } \\
\text { Dance, Architecture, } \\
\text { Craftsmanship, Gombas }\end{array}$ & $\begin{array}{l}\text { Best view of Langtang, } \\
\text { Sanjen, Goshaikunda range } \\
\text { from Goljung view point, }\end{array}$ & $\begin{array}{l}\text { Ghale Darbars, } \\
\text { Meditation Places }\end{array}$ \\
\hline Gatlang & $\begin{array}{l}\text { Tamang culture, Syabru } \\
\text { Dance, Architecture, } \\
\text { Craftsmanship, Gomba }\end{array}$ & $\begin{array}{l}\text { Beautiful wetland } \\
\text { (Parvatikund), Dense } \\
\text { forest, Orchids and } \\
\text { Rhododendron forest, Best } \\
\text { view from Khurpu Danda, } \\
\text { cheese factory, water mills. }\end{array}$ & \\
\hline Chilime & $\begin{array}{l}\text { Fusion of Tamang and } \\
\text { Tibetan culture, Syabru } \\
\text { Dance }\end{array}$ & $\begin{array}{l}\text { Natural hot spring, Sanjen } \\
\text { Himan, Sanjen Kharka, } \\
\text { Sanjen valley }\end{array}$ & \\
\hline Thuman & $\begin{array}{l}\text { Tibetan culture, Tibetan } \\
\text { Dance, Unique } \\
\text { architecture, } \\
\text { Craftsmanship, Gombas }\end{array}$ & $\begin{array}{l}\text { Scenic landscape of } \\
\text { Nagthali, Best view of } \\
\text { Langtang, Kerung, Sanjen } \\
\text { Himal range from Nagthali }\end{array}$ & \\
\hline Timure & $\begin{array}{l}\text { Tibetan culture, Tibetan } \\
\text { Dance, Craftsmanship }\end{array}$ & $\begin{array}{l}\text { Bhotekoshi river valley, } \\
\text { Dudh Kund lake }\end{array}$ & $\begin{array}{l}\text { Historical war } \\
\text { Fort at Borderland }\end{array}$ \\
\hline Briddim & $\begin{array}{l}\text { Tibetan culture, Tibetan } \\
\text { Dance, Unique } \\
\text { architecture, } \\
\text { Craftsmanship, Gombas }\end{array}$ & $\begin{array}{l}\text { Green forest, Musk Deer, } \\
\text { Pheasants, Snow Leopard, } \\
\text { Pangsang Himal, River } \\
\text { Kund lake }\end{array}$ & \\
\hline
\end{tabular}

Source: Rasuwa Smarika 
Cultural resources are human-made. They are artificial and constructed, whereas natural resources are more distant, both geographically and conceptually. They are the remote raw ingredients of human material cultural life (Willow, 2011, p.114). Willow further points out cultural significant natural resources must begin by acknowledging that all natural resources are culturally significant in some way, shape, or form. Culturally significant natural resources comprise the plants and animals, rocks and minerals, the water and waterways and the landscape of ecosystems that contains cultural meanings for the people who use, relate to, and behold them(Willow, 2011, p.115).

According to King(2011, p.2), cultural resources are all the aspects of physical and supra-physical environment that human beings and their societies value for reasons having to do with culture. Included are culturally valued sites, buildings, and other places, plants and animals, atmospheric phenomenon, sights and sounds, artefacts and the other objects, documents, traditions, arts, crafts, ways of life, means of expression, and systems of belief. sometimes terms like heritage are used to mean roughly the same things, or have overlapping meanings(2011, p. 4). Morse- Kahn (2011, pp.128-140) opts for 'resource' defined- paraphrasing the Merrian-Webster dictionary- as "a source of supply or support", or "a source of wealth or revenue", or "a feature of phenomenon that enhances the quality of human life".

Hence, Tamang Heritage Trail (THT) developed by TRPAP promoted community tourism and sustainable tourism in Rasuwa. The pro-poor concept stressed upon homestays and community lodges to address the problem related to accommodation in the area. Irrespective of natural settings THT offers ethnic group(Tamangs)with different art and architecture, sculptures, folk dance/music and musical instrument and local craftsmanship, festivals, religious-cum-cultural beliefs, specific local fairs, and monumental heritage-forts, chortens and mani of the historical and artistic value and other places of attraction that highly motivate tourist regarding ethnic authenticity and heritage tourism by tourists. The combination of cultural needs of the tourist and the cultural products by the localization of the resources with several trainings provided by TRPAP helped Gatlang to foster ethnic and heritage tourism. Till now the scholars and researchers of Nepal have not seen the ethnic tourism through the lens of hostguest interaction.It is important, however, to realize that native ethnic groups themselves actively collaborate in the ethnic tourist experience.

\section{Works so far done}

Smith (1989,pp.4-5) distinguished ethnic tourism from cultural tourism. 'According to her definition, on the one hand , the tourist attractions of ethnic tourism are "quaint customs' of indigenous and often exotic people ," and , on the other hand, the attractions of cultural tourism are "'picturesque' or 'local color ,' a vestige of a vanishing life style that lies within human memory" (Smith,1989, p.4). It seems that she did not intend that the two definitions should be distinct, as she did not make a rigid distinction 
between the concept of ethnic tourism and that of cultural tourism. Also she has used the term ethnic, cultural and indigenous interchangeably and the distinction is also not much clear and is questioned several times.

Wood (1984, pp. 359-62) criticized the vagueness of Smith's definitions of ethnic and cultural tourism, and presented his own definitions of them from the perspective of "the tourists' approach to cultures." "Ethnic tourism," according to Wood, "should be defined by its direct focus on people living out a cultural identity whose uniqueness is being marketed for tourists" and, on the other hand, "cultural tourism may be defined in terms of situations where the role of culture is contextual." Cultural tourism, according to Wood, enables tourists to experience exotic cultural situations and atmosphere (Wood 1984, p.361). Wood further divided ethnic and cultural tourism into four types from the perspective of 'primary' or 'secondary' roles of culture and ethnicity in tourism: ' primary' ethnic and cultural tourism (Wood1984,pp. 361-362). By means of characterizing ethnicity and culture respectively, he distinguished ethnic tourism from cultural tourism.

However, two problems can be pointed out concerning Wood's definition. The first problem is that the connotations of 'culture' as a tourist attraction is too limited in Wood's definition. The connotation of his definition covers only unmodernized or unwesternized culture. The term 'culture' as a tourist attraction should include both connotations of unmodernized and modernized culture. 'Cultural' tourist attractions, therefore, can be seen to include theme parks, museums, theaters, sports, outdoor recreation and so on (Urry, 2002). The other problem is that ethnic and cultural tourism are placed on the same conceptual level in the definition by Wood. The concept of 'ethnic tourism' should be subsumed within that of 'cultural tourism', because ethnic peoples and their exoticism as tourist attractions in ethnic tourism can be regarded as elements of a culture.

MacCannell(1992) has elaborated the origin, components and importance of ethnic tourism. He further has stated the importance of anthropology of tourism to study the ethnic tourism and indigenous tourism has also to be discussed while considering ethnic tourism. The focus is on a type of authenticity-for-tourism in which exotic cultures figure as key attractions: where the tourists go to see folk costumes in daily use, shop for folk handicrafts in authentic bazaars, stay on the alert for a typical form of nose, lips, and so on, learn some local norms for comportment, and perhaps learn some of the language. The concern here is not with the often bizarre results of the tourists' efforts to 'go native'. Rather, it is with the natives' efforts to satisfy the touristic demand, or to go native-for-tourists." In certain contexts broader terms such as cultural and ethnic (Swain,1993) tourism have also been used to encompass the indigenous tourism dimensions in whole or in part. Indigenous tourism refers to tourism activities in which indigenous people are directly involved either through control and/or by having their culture serve as the essence of the attraction. 
As per Rodrigo de Azeredo Grünewald (2006), ethnic tourism can be understood using two distinct perspectives: one that looks to the object of tourism, and in this case, the native who is the focus of the trip; and another perspective that would take up ethnic tourism by what the tourist sees or finds during his or her visit. The idea of tourism, in fact, seems to fall on the perspective of those who travel. If, however, the perspective was shifted to that of the native, it would be precisely the ethnicity exercised in the terms of a cultural production of traditions to be exhibited as distinctive features within the touristic ambit that would signify the ethnic character of the interaction. And this would be the case even if it occurred without the natives completely understanding it or without a formal plan for the development of tourism in their village. Therefore both the emic and etic approaches has to be considered through the lens of natives as well as tourist because the visual impact is very important. Rodrigo de Azeredo Grünewald (2006) has further defined tourist as- The touree is the native when he begins to interact with the tourist and modify his behavior accordingly. The touree is the native-turned-actor -whether consciously or unconsciously - while the tourist is the spectator. The middleman is the broker in ethnic exoticism who mediates and profits by the interaction of tourist and touree, and who, in the process, very frequently manipulates ethnicity for gain, stages "authenticity," peddles cultural values, and thus becomes an active agent in modifying the situation in which and from which he lives. With all of this it can be seen how far ethnic tourism really is from cultural tourism, or that tourism which can be defined "in terms of situations where the role of culture is contextual, where its role is to shape the tourist's experience of a situation in general.

While dealing with ethnic tourism the problem of authenticity and commoditization should also be dealt regarding the cultural product and hospitality. Due to the demand of tourist, the natives promote their traditional customs to promote authentic experience to tourists. This is the cultural involution refering the emphasis to the traditional and original culture of the natives. For example, traditional costumes, traditional means of agriculture, traditional domestic archives and the like. With the growth of tourism, the people showcase the traditional dances, songs with cultural modification. This is regarded as commoditization through changing culture. The balance between the living culture and model culture should be maintained to attain productive tourism through cultural preservation and additional values(income) to the culture. This research raised the importance of authenticity and commoditization in the promotion of tourism in Gatlang. The economic and socio-cultural impacts of tourism is dealt to promote the balance between cultural involution and contextual cultural change to maximise the benefits of tourism in the study area.

The concept of ethnic tourism has not yet been defined clearly (Harron and Wiler1992; van den Berghe and Keyes1984). At times, ethnic tourism tends to be confused with cultural tourism (Smith, 1989, pp. 4-5; Wood, 1984, p. 359-62). 
Tourists frequently are searching for 'authentic' souvenirs and traditions within the indigenous communities. According to Michael Harkin (1995,p. 662)they may be searching for these 'authentic experiences', but he notices that tourist attractions are no longer completely authentic, as they are "already framed and often over-determined". He relates this fact also to souvenirs, which can be anything that is part of the touristic experience and represents the experience. It depends on the ideas of the tourist what kind of representation he values and if he finds something 'authentic' or 'traditional' (1995, p. 657). Eliza Wethey (2005) distinguishes a difference between tradition and traditional, as these have different meanings. She states that a tradition is a set of practices that is changeable and passed on from one generation to the next, while something traditional is static or unchangeable and often even associated with resistance to change in contrast to the modern and urbanized world. According to Wethey (2005) many tourists see traditional textiles as those that are produced in indigenous communities using natural dyes, and ancient techniques and patterns and therefore they are more associated with the traditions of the past instead of a reflection of the present. She sees that weaving communities in Mexico, Central America and the Andes start commoditizing their traditional weavings "in order to take advantage of tourists' desire for ethnic goods, which provides them with the opportunity for income and life improvements" (2005, p. 5).

Wang (1999) gave taxonomy of three types of authenticity in tourist experiences: object-related authenticity in tourism-refers to the authenticity of originals; existential authenticity-refers to a potential existential state of being that is to be activated by tourism activities; constructive authenticity-refers to the objects by tourist or tourism producers in terms of their imagery, expectations, preferences, beliefs and powers. Handler and Saxton(1988; Bruner, 1994; Wang 1999; in Belhassen et al., 2008) recognized that the term 'authenticity' has not been used consistently in the literature, suggesting that the various uses of the term can be found across studies and, at times, even within the same study (Bruner, 1989; Cohen, 1988; MacCannell, 1973). Through a geneological meta-analysis, Wang (1999) maps out conceptual developments of the term over the last four decades, and concludes by suggesting a classification of the different theoretical approaches toward authenticity in tourism studies. Hypothetically, this originality can be measured with objective criteria that determine whether the object is authentic or not. This approach may be affiliated with the broader academic stream of objectivism and, to some extent, with post-positivism and empiricism, all of which presuppose the existence of authenticity as a quality that can be measured. However, this approach, as reflected in the writings of Boorstin(1964) and MacCannell (1976), does not specify how or by whom these criteria are established (in Belhassen et al., 2008).

Commoditization is the process of making something, an event, ritual, performance or even people into a commodity, an article of trade, evaluated in terms of their 
exchange value. It has, in general, a negative undertone when it is applied to cultural heritage, rituals, traditions, and customs (Jafari, 2000, pp.91-92). It might be interesting to see what happens to the other meanings (changed meanings)of things and services once they become commoditized, particularly under the impact of tourism. It is possible that tourism destroys or changes the meaning of cultural products, as they are commoditized, but tourism can also mean that customs, rituals and traditions remain alive when they become tourist attractions, especially if they were already in decline before tourism appeared (Cohen, 1988). According to Greenwood (cited in Cohen 1988, p. 381) commoditized cultural products lose their intrinsic meaning and significance for the local people, who in turn lose their enthusiasm for producing them. The ritual may become a performance for money, which may lead to exploitation of the locals by 'culture-brokers' or affect the culture product itself as it becomes a tourist attraction. Cohen(1988)finds the idea that commoditizing means loss of value an overgeneralization as artists will always be proud of their performances, like weavers will often be proud of their weavings. Even new cultural products can be accepted as 'authentic', and become meaningful for its producers. Just like the emergence of tourism can actually facilitate the preservation of a cultural tradition which otherwise would die out (Cohen, 1988, pp. 381-382). Tours can be arranged to visit the communities, souvenirs made out of rituals and the traditional costume can be turned into commodities.

The problem of 'commoditization' has occurred when culture and ethnicity, which were not originally regarded as economical properties, were incorporated into the modern economic system, particularly the capitalist economic system, as tourist products. The feature of the capitalist system which can be seen as an impelling force of modernization is the principle that "anything that can be priced can be bought and sold" (Greenwood, 1989, p. 173). There is no exception for the case of tourism in general nor for ethnic tourism. Through ethnic tourism, culture and ethnicity have became the direct object of 'commoditization.' Concerning commoditization and modernization, most people all over the word recognize the view that 'commoditization' arises from modernization and that this is an inevitable and irreversible trend. Mass tourism is rather seen as a factor quickening the process of commoditization.

Indigenous peoples who have chosen tourism development through ethnic tourism do not have the choice of refusing modernization. The acceptance of mass tourism through developing ethnic tourism inevitably introduces modernization along with commoditization of the hosts' culture. The fact of change and destruction of 'authenticity' through 'commoditization' is widely recognized. The problems of 'authenticity' and 'commoditization' are actively inter-related, and give rise to different questions. For example, tourists of ethnic tourism tend to demand the maintenance of authenticity to provide a sense of exoticism, whereas governments of developing countries and some indigenous peoples are prepared to accept commoditization in order to promote 
modernization of their society or community). In ethnic tourism management, social conflicts often arise from the difference of respective standpoints. Further, ethnic tourism management has a dilemma: the more tourists seek for 'authenticity' of ethnicity as a tourist attraction, the more its 'commoditization' spreads and then 'authenticity' disappears (van den Berghe and Keyes, 1984).

These problems concerning 'authenticity' and 'commoditization' pose complicate and serious questions to ethnic tourism management. In contrast to these questions, a practical goal of ethnic tourism management at present is to optimize the balance between 'authenticity' and 'commoditization'. In order to achieve the goal, the question will be presented again: 'who' insists upon authenticity and how.'

Cohen (1974) points out that an expansion of a group's resource base outside its boundaries will alter the degree of dependence of occupational roles on outside resources. In case of tourism the outside resource is tourist. Smith (1989) said that tourists prefer small, inexpensive souvenirs which in turn require less raw materialsa desirable factor, too, in wildlife conservation. Further, the new cultural self-confidence and the quantity of native-made items have all but eliminated the plastic tinkers of former years and even "fake art" carved from African vegetable ivory. Likewise the crafts and dolls made from cotton, fabric and wood can be the good example with the less use of raw materials as souvenirs to tourist with the promotion of culture and ethnic tourism. Further she adds that indigenous tourism development will be selfsustaining when the financial, political, economic, and institutional aspects help to support on-going tourism efforts.

Many successful cases of ethnic tourism have been reported;they include, for example, Cajuns (Esman 1984), Athapaskan Indian (Jarvenpa 1991), Navajo (Jett 1990) and Balinese (McKean, 1989; Picard, 1993). In all these cases, success in the expression of the culture and gaining benefits through tourism can be pointed out. One criterion of success is when, by means of ethnic tourism, indigenous peoples or regional residents realize their own culture and then build and preserve their identity.They enrich their self-respect and group loyalty through expressing their own culture and value to tourists. The common tourism process in these successful cases means that, through ethnic tourism, indigenous peoples accept modernization and commoditization and, at the same time, reconstruct, maintain and intensify their particular culture. Such tourism process can be characterized by the 'cultural involution' indicated by McKean (1989) in the case of Bali. Bali is one of the most successful cases of ethnic tourism.

Culture involution optimizes a balance between authenticity and commoditization. The common feature of management among these cases signifies that hosts 'themselves' voluntarily construct their own culture and values--even if tourist activity in some of these cases was started by outsiders--and represent their own culture and ethnicity to tourists. This may be an answer to the question stated above, as to 'who' insists 
upon authenticity, and can be considered as the first maxim for ethnic tourism management. (Mckean 1989, pp. 125-130).

Ethnic tourism characterized by 'cultural involution': hosts should take the initiative in managing ethnic tourism). The case of Bali has often been introduced as a good example of host's initiative in ethnic tourism management. In 1968, experts, who were asked for advice about tourism development in Bali by the Indonesian government, recommended that a part of the island of Bali should be developed as an 'enclave' for tourists, so as to avoid the destruction of the valuable ethnicity and culture of Bali. (McKean, 1989, pp. 119-138).

Unless the prerequisites are met, a host community managing ethnic tourism would be confronted with real problems such as acculturation, the disappearance or destruction of culture, and loss of identity (Crystal 1989; Greenwood 1989; Swain 1990). A method of ethnic tourism management which provides the prerequisites of cultural involution and at the same time protects the culture from destruction is the 'model culture' (Stanton, 1989). This method aims to preserve the culture and life style of the hosts by constructing an 'overt tourist space' (Cohen, 1979, p. 28) as a 'model culture.' 'Model culture' is the concept presented by Stanton (1989, pp. 247264) in describing the management methods of the Polynesian Culture Center (PCC) in Oahu, Hawaii.

However, tourism even if balanced by cultural involution or changing culture has two contrasting perspectives regarding the socioeconomic impact of ethnic tourism on local minority residents (Adams, 2006; Boswell, 2005; Bruner, 2005; Hitchcock, 2000; Middleton, 2004, p. 73; in Ishi, 2012, p. 293). The first widely accepted perspective is that ethnic tourism has multiple benefits, such as cultural/identity revival and socioeconomic, and sometimes even political, gains for local minority residents (Adams, 2003, p. 571). These scholars often challenge traditional arguments that question the authenticity of minority culture that is reproduced on behalf of tourism (Gru"newald, 2002, p. 1016). In contrast, the second perspective maintains that ethnic tourism provides a limited economic return for local minority residents, although many scholars do acknowledge the positive impact of ethnic tourism on cultural/identity grounds (Cohen, 2001). Some studies point out situations where locals tolerate tourism's unwanted effects (Andriotis, 2006, p. 1082). According to these scholars, minority residents accept ethnic tourism despite the limited economic return because of its positive impact on the revival of culture and identity, which transcends the limited economic return (McKercher \& Fu, 2006, p. 521; Nepal, 2005, p. 116; in Ishi, 2012, p. 293). Existing scholarly literature has focused on the analysis of the socioeconomic impact of tourism based on whether local residents participated in the tourism industry or not (Li, 2006, p. 133; in Ishi, 2012, p. 293).

Swain argues that in minority societies engaged in tourism, women often lead in the production and sale of ethnic goods (Swain, 1993, p. 35). This gendered artisan 
production can rarely support an entire family, but it is, nonetheless, a source of income that is much more significant for ethnic identity than other forms of work in the state society (Swain, 1993, p. 44). The success of women's sales of textile art promotes women's economic self-sufficiency and thus changes gender dynamics within the group (Swain, 1993, p. 46). However, at the ethnic group level, women are not empowered because most women conform to cultural ideas of male and female roles within their own local and state societies (Swain, 1993, p. 48). This socioeconomic situation induces gender antagonism within the household. Patriarchal rule is challenged by the gender division of household labor in which women are now the main household income provider, but cultural ideology continues to reproduce social forms of ethnic identity (Swain, 1993, p. 42).

Kunwar (2010, p. 55) elaborates destination activities characterized by visiting native homes and villages for observation of dances and ceremonies, and shopping for primitive wares of curios. As long as the flow of visitors is sporadic and small, host-guest impact is minimal. This kind of tourism can be developed in different areas of Nepal.

Dhakal (2011) has highlighted the role of TRPAP in enhancement of livelihood and poverty reduction. TRPAP piloted its innovative model of pro-poor, pro-women, pro-community, and pro-environment tourism in the selected areas of six districts. Taplejung and Solukhumbu in the Eastern Development Region; Rupandehi in the Western Development Region; Rasuwa and Chitwan in the Central Development Region; Dolpa in the Mid Western The program demonstrated that livelihoods can be improved and poverty can be reduced through community involvement with community aspirations. Through this approach the poor were availed of better access to capacity building and financial resources. Ownership by the local community and continuous and meaningful community participation are essential for the sustainable development of rural tourism. TRPAP have contributed to capacity enhancement and increasing local people's access to financial resources through the provision of soft loans for small business ventures. Social mobilization was an integral part of the program. Almost all households in the program areas were given opportunity to be trained in vocational areas, empowered to understand the value and importance of their social belonging, facilitated and mobilized to define their priority needs, and helped to identify their objectives and design a sustainable process to achieve results. In broad sense, the aim of the program was to manage the human, economic and organizational resources to increase and strengthen community participation.

\section{Research Methods}

Methodology is not just a set of research techniques; rather, it is the set of principle that guide research. Research method concerns how one conducts research, analyses the data or evidence, test theories and creates new knowledge(Rosenau, 1992; in Kunwar, 2012, p. 2). Using a variety of methods, rather than concentrating on one 
method, will help to overcome weakness, as there is no single ideal method of research in behavioural sciences (Sommer and Sommer, 2002; in Kunwar, 2012, p.2).

Methodologically, this work is based on the interdisciplinary approach to identify and study new themes that single disciplines would not be able to put into focus, describe interpret by themselves. As the research synthesize more than one approach in regard with ethnic tourism correlating cultural tourism, heritage tourism, indigenous tourism, authenticity and commoditization. Because ethnic tourism cannot be defined without considering culture tradition and its authenticity with the challenge of commoditization.

Among the various qualitative research methodological approaches (case study, ethnography, ethnomethodology, phenomenology, grounded theory and participatory action research). The research has been carried out using qualitative research in order to describe the findings of the study in natural setting. The specific informations were gathered about ethnic tourism and collected data were interpreted.Information was gathered through participant observation to attain the perceptions of host as well as guest and analyzed carefully. The qualitative research has been carried out to attain in depth view of the respondents through participant observation and in-depth interviews through continuous interplay between data collection and analysis.

The convenience sampling has been applied in this research. The population of the study were homogeneous in nature with the ease of access and hence, convenience sampling was used to select the respondents for the conduction of the research.The houses are alike with same family structure and almost same sort of economy and so on. Out of 402 household, 30 household (some of the lodge owners and home stay owners and some villagers) were closely observed to attain emic(insiders' version) view of community and 30 tourists were interviewed to attain the etic (outsiders' version) view of the tourists.

For this research fieldwork was conducted for 15 days in both Lantang region and Gatlang areas.

Primary data were collected through close observation and in depth interview with the respondents with the help of structured but unstructured questionnaire to attain first hand informations and datas.

An extensive desk study was conducted for the collection of relevant secondary information. The secondary data sources involved a wide range of materials such as books, study reports, annual reports, journals and so on. Apart from library research, internet browsing for the relevant materials also proved to be of immense help to understand the issues regarding ethnic tourism.

\section{Tourism in Rasuwa}

The history of treaking in Langtang region goes back to 1970s and this area was first explored by Eric Shipton in 1950s (Odell and Lama, 1998, p.199). Tourists in 
Rasuwa mainly are the trekkers; visiting Lantang $(3,420 \mathrm{~m})$ and Gosainkunda $(4,381 \mathrm{~m})$ as natural trekkers and visiting Tamang Heritage Trail as cultural trekkers. The statistics of tourism profile of 2011 shows that the total 13,838 tourist visited Langtang National Park. The trip to Rasuwa is adventurous filled with cultural and natural landscapes. The authentic culture combined with serene nature gives the complete package for tourism as a product and attraction to the tourist. Major areas of cultural attraction are Gosaikunda, Langtang valley (a fusion of Tibetan and Tamang culture), GatlangGoljung areas (living heritage of Tamang culture and architecture), Kyangjin (3,900m) and Sing Gomba (oldest Buddhist monastery)(3,304m).

However, during the project time of TRPAP, 5,276 people visited THT out of 43,300 . the exact factual sheet is unavailable in present context because the project has already phased out and the government has not conducted further research of THT.

Table-2: Distribution of tourists by year visiting Rasuwa and the THT

\begin{tabular}{|c|c|c|}
\hline Year & Visitors to Rasuwa District & Visitors to Tamang Heritage Trail \\
\hline 2002 & 29,880 & 1,220 \\
\hline 2003 & 28,660 & 1,435 \\
\hline 2004 & 25,215 & 1,705 \\
\hline 2005 & 35,400 & 5,135 \\
\hline 2006 & 43,300 & 5,276 \\
\hline
\end{tabular}

Source: DDC, Rasuwa and TRPAP

\section{The Tamang Heritage Trail/Trek}

As part of the Tourism for Rural Poverty Alleviation Programme(TRPAP), the Nepal Tourism Board initiated the Tamang Heritage Trail as a Pro-Environment, ProCommunity, Pro-poor and Pro-women project. It unfolds the rich Tamang culture with its history, monuments and the like. THT is primarily rich in Tamang culture, tradition and architect supplemented with hot spring water, historical war fort and natural attractions as ancillary products. The trail follows the row of Chhorten (small stupa) from Gatlang to Timure along the old trade route to Tibet. Tamang Heritage Trail passes through the mountain villages where the traditional architecture, crafts and style of dress has remained unchanged. Culturally rich villages like Gatlang, Goljung, Thuman, natural spring hot water at Tatopani, beautiful landscape of Nagthali, historical war fort at Rasuwa Gadhi and Home-stay village packages at Briddim are the prime areas of tourism attraction in THT. Hence, the heritage within the Tamang ethnicity of people residing in the trail through the micro and macro lenses of ethnic and cultural tourism and complete as heritage tourism. 
Table-3: Itinerary for the Tamang Heritage Trail

\begin{tabular}{|c|l|l|l|}
\hline Days & \multicolumn{1}{|c|}{ From } & \multicolumn{1}{c|}{ To } & \multicolumn{1}{c|}{ Time } \\
\hline 1 & Kathmandu & Dhunche/Syabrubesi & 7 -8 hours drive \\
\hline 2 & Syabrubesi & Goljung-Gatlang & 1hour and 45 minute drive or 4 hours walk \\
\hline 3 & Gatlang & Tatopani & 6 hours walk \\
\hline 4 & Tatopani & Thuman & 5 hours walk \\
\hline 5 & Thuman & Timure & 5 hours walk \\
\hline 6 & Timure & Briddim & 6 hours walk \\
\hline 7 & Briddim & Syabrubesi & 3 hours walk \\
\hline 8 & Syabrubesi & Kathmandu & 7-8 hours drive \\
\hline
\end{tabular}

Source: Lonely planet

\section{Cultural Attractions of Gatlang village}

Gatlang is one of the largest ethnic villages situated in the moderate climatic region. The cluster-shaped houses can be seen from the distant. It is believed that the ancestor with the motive to protect themselves from wild animals and other dangers started living in cluster. According to the survey conducted by the school and VDC of Gatlang; there are 402 households with 2119 of total population(1091 males and 1020 females). Mainly the Tamangs follow two religions: $343 \mathrm{H} / \mathrm{H}$ are Budhhist and $59 \mathrm{H} / \mathrm{H}$ are Christians(VDC,Rasuwa). However, both of the groups follow mutual cooperation at hard times. The $90 \%$ of the total population are literate. The total population of Rasuwa is 43,300, out of which 29,782 are the Tamangs (CBS, 2011) who have settled in different villages of Rasuwa district.

\section{House structure}

The structure of the house looks alike in every aspect. The small wooden planks tighten together with bamboo ropes from inside, the walls are of stone and partition is made from wooden planks/plies. The doors and windows are artistic engraved with wooden carvings. However with changing time, the carvings are less than old settlements.

The ground floor of the house is used as storage of firewoods, planks, stones, grains and chicken coop in every house. All the family members used to sleep in the same room but now the partition of room is done: one for elderly member and one for the youngsters. The open kitchen with improved cooking stoves, traditional cooking pattern or gas stoves and traditional utensils are noticed. Attar - a separate corner for worshipping -holds religious importance and prohibited for the outsiders. The wooden balcony with carvings is yet another attraction of the village.

After the incentives (capacity building, awareness trainings) from TRPAP, people are aware of sanitation and hygiene, and every house has one toilet outside of the 
house but within the compound. With the concept of home stays, people have managed a room of twin or group sharing in most of the houses.There are altogether 108 manis(the long free standing stone walls inscribed with Tibetan mantras), and many chortens in Gatlang.

\section{Products}

Destinations that selectively transform cultural resources into tangible products not only facilitate the exchange of this cultural experience for a financial return, but have the potential to create a situation in which the destinations can promote sustainable development through careful management of resources. Likewise, with the introduction of TRPAP ,the women have transformed the cultural practice of knitting and weaving into products in tourism. The training provided them the exposure to income with the manufacture of souvenir. They weave bakhhu, rug, kammal (blanket) from yak and sheep wool, and the cultural cap is very famous and most tourists like to buy it. Other handicrafts are: patuka (waist belt of cloth), radi, kammal, bakhhu (traditional jacket) mobile bags and seldom (a special shirt). Parma (reciprocal work for mutual co-operation) is the process of manufacturing mass goods with the involvement of women in weaving and knitting in leisure.

\section{Social institutions}

The male member seems busy with livestock and other labour work during day time. The firewood collection, timber collection, renovating houses and playing cards are the responsibilities of men. However, women are busy in parma (reciporcal work) and weaving rugs and bakhhu (overcoat) in traditional taan (handloom) Also at the time of crop harvesting in off season both men and women work together in field. However, the men cook food and do physical labour as compared to women of the community.

Social institutions are the structures and mechanisms of social order and cooperation governing the behavior of a set of individuals within a given human collectivity. The ancestors preferred joint family for family bond and safety. Almost three generations used to live under the same roof sharing family ideologies and profession. Now, the preference is given to nuclear family. After marriage, people prefer nuclear family. However, the mother of bride is the responsibility of the groom. Arrange marriage, mutual agreement (love marriage), elopement and marriage by capture are popular forms of marriage among Tamangs of Gatlang. Ancestors used to practice polygamy which is replaced by monogamy in young generations. All the cost of marriage has to be borne by the grooms' family. After marriage, mother moves with her daughter to her son-in-laws' house. It is a tradition in Gatlang that groom has to look after his mother-in-law (wife's mother). In such case, all the ancestral property is given to daughters, otherwise there is an equal share between son and daughter. Widow and widower marriage is also common in Gatlang. However, if someone elopes with 
another man, the man has to pay the double amount of the cost of marriage to first husband. Syangden, Lopchen, Teb are the clan group among Tamangs. Syangden and Lopchen are allowed to nuptial relation. Similarly, Syangden and Teb also marry traditionally. However, Lopchen and Teb are not allowed to get married as they are said to come from the same ancestor. Cross-cousin marriage is also allowed to get married. However, the concept of family planning is highly accepted by the young generation and contraceptives devices are remarkably used but the old generation discard the use and concept both. Tungana (traditional instrument)is played and dohari geet (competitive duet song) is popular in marriage with wine ceremony.

Lama is the priest who keeps name of the child after a week of birth and it is called chewar. But it was not practised in ancient time. Death ceremony is very different in the community. It is called ghewa. The dead body is burned and the Lama decides a day that is considered to be a good omen day to make chortens in the deceased's name. The Lama (priest) is invited after a week to recite scared mantras. Then rice, vegetables and other foods are served to all of the people attending ghewa.

Separate justice system prevails in the village. People of the village elect a chief known Raja and his assistant for one/two year for the justice to the local affairs and cultural preservation. The Raja thus elected holds special power to resolve conflict within a family and society. They settle disputes, levy fines and mete out punishments. They have rights to organize fairs and events in festivals, and decide to construct any social systems in favor of the community. However, many critical cases of theft, burglary and unjust are resolved through Police Station in Syabrubeshi. Mainly Shamansim is practised as healing method in the village.

After the introduction of the project, many awareness trainings were conducted for the communities. These trainings included family planning, gender roles and sanitation. This has helped people to use contraceptives and follow proper family planning strategies. However, the older generation denies the concept of family planning.

\section{Attractions}

The culture, tradition and customs, settlements, architect, surrounding mountains and landscape, nearby spots and forest are the major attractions of the village. Hence the natural and cultural combination add significance to the cultural heritage tourism of Tamangs. The performers play an active role in presenting ethnic culture as well as communicating with tourists. Such cultural exchange opportunities may not only provide visitors a chance of appreciating ethnic cultures, but also help them build a sense of pride of their culture. The house pattern, the domestic archives, the architecture, Parvati Kunda (lake), cheese factory, chorten and monastery (also called ghyang and gumba) water mills, village walk, traditional tilling and ploughing system and local wine brewing and tasting are the major attractions of Gatlang. 


\section{Customs and Traditions}

The traditional Tamang dress is the major attraction of the village. Male and female specially elder men and women are seen in their special attire. However, young women also wear Tamang dresses but the dressing does not seem complete as compared to that of old people. Women wear angdu(long garb) coat, guni (syama), syade (cap), pani (shoe), kangsyup (socks) and che (waist belt) and ornaments like budil (earring), kolda (beads), thoka (bangles). Men wear- bakkhu, seldom (shirt), khanja, suruwal (trousers) and ornaments like budil (earring). People while making move outside their home will hold khukuri (knife) around the waist.

Tungana is the traditional instrument of the Tamangs of Gatlang. The villagers play folk songs through tungana during marriage and other festivals. There are wine festivals in the community. Baishaki is one of the wine tasting festivals of Gatlang.The whole villagers gather together in GLCC and perform folk dance and sing folk songs. The villagers are seen in their colorful traditional dress enjoying the folk dances. The dance holds its own importance as the two groups are portrayed as fighters (beneath masks) of Tibet and Nepal. It is believed that Tibet and Nepal fought at the time of their ancestors resulting into casualties to both sides. Hence, they stopped fighting and started living without prejudice. Similar story is presented with the moral that fight and wars end with the loss of either property or lives but peace prevails in mutual cooperation. The joy of cooperation is rejoiced with folk songs (Tamang Selo). People enjoy new dresses and celebrate yet another year of co-operation on the first day of Baishakh (March-April).

Janai purnima, one of the biggest festivals which is celebrated by the Hindus in between August-September. The Tamangs also participate on this festival which is celebrated at Parvati Kunda. The medicinal herb called Bojo is used by Jhankri for healing and it is highly found in Parvati Kunda. The Jhankri dance in performed in midnight. Only males are allowed to participate in the festival by tradition. It is also the festival of wine.Teej is not much popular although women celebrate it with great faith for the long life of their husbands. Women have acculturated this festivals after the trail is opened. Women also began to travel and get influenced by the festival and started to fast for the longevity of their husbands. Dashain (one of the biggest Hindu festivals) is celebrated in a different way. People (specially male) put tika(rice mixed with blood of animals) from elders (specially male) and receive blessings, and sacrifice goat and hen. The locally grown wheat is ground in water mill and bread is prepared to celebrate the festival. The male again are seen busy playing cards and drinking while female are busy cooking and serving. The first day of Magh (Jan-Feburary) holds another important place in celebrating the harvesting year. All the crops grown annually are cooked together (khole; thick mixed soup) as a celebration of good harvest year. They eat and drink together but only male members are permitted to drink alcohol. 
However, the tourist are deprived from experiencing festivals on their own. Though they enjoy the narration of the guides regarding these festivals, they are still eager and curious to see and experience them. However, there is no initiative taken by the Government to make an alternative arrangement for this purpose. But at the local level, people are trying to make an alternative arrangement on their own in order to serve the interests of those tourists who are interested in experiencing or attending these festivals. For example, some lodge owners are collaborating with local people to document these festivals through audiovisual mode. This would help those inquisitive tourists to, at least, see those feasts and festivals.

\section{Livelihood}

Animal husbandry is the major source living in the village whereas tourism is seasonal. Cow, goat, sheep, chauri, chicken are reared. The off season agriculture yields are potato, beans, barley, maize, millet, garlic. They are self consumed but beans, manures and potatoes are sold in nearby market and even to headquarter (Dhunche). However, tourism is seasonal yielding good exposure to the host community. The locals are highly benefited through tourism; the people with the training by TRPAP satisfy the tourist with variety of breakfast and lunch of their choices. The traditional food of Tamangs; dhindo (porridge)and gundrukko achar(fermented mustard leaves), khole are also served on request. Agriculture, tourism and animal husbandry are the chief sources of income.The soft loan provided by TRPAP has been used to add animals which has yielded in additional manufacture of souvenirs with the addition of livestock.

\section{Leisure}

Free time is used in searching grazing lands for animals and playing cards by men. Also alcoholism is visible among the older generation of men however women are busy knitting and weaving in leisure with the involvement in parma(indulgence of women in mass production of souvenirs, collecting firewoods, harvesting maize).

\section{Accommodation}

Though there are already 55 lodges in Langtang National Part (Thapa, 2014), Gatlang village comprises one community lodge i.e. Gatlang Lodge and Cultural Center(GLCC), 4 Homestays and two Lodges that offer accommodation facilities. The community lodge receives more group tourists (with guide) than individual tourists. The oldest hotel in Lantang region is Lama hotel which was run in 1973 (Bezruchka, 2001, p. 251). In Gatlang the lodge offers cultural programs featuring local wines and food. The bed charges are free whereas the nominal price is charged for food. However, the homestay offers close interaction regarding the lifestyle, domestic archives, sleeping pattern, cooking systems, dressing patterns and human behaviour. The lodge is not popular choice among the tourists because it is more commercialized and less authentic in relation to the original culture of Tamangs of the village. According to Lynch (2005b; in McIntosh et al., 2010, p. 3), homestay is 
also defined as commercial home. In Gatlang, home stay offers such type of accommodation where visitors or guests pay to stay in private homes, where interaction takes place with a host and/or family usually living upon the premises and with whom public space is to a shared to some extent. Therefore, the host and tourist both prefer homestay as compared to lodges and community lodge. Tourists find their stay more authentic and enjoyable in home stays.

\section{Homestay}

As cited by Weaver (2006), Dernoi (1981), for example, defined it as a form of tourism in which visitors are accommodated in the houses of local residents. This mode of alternative tourism, commonly referred to as homestaytourism, was in fact well articulated by the late 1970s, with formal programmes in Denmark ('Meet the Denes'), Jamaica ('Meet-the-People') and the US state of Connecticut ('Friendship Force'), among other destinations. Dernoi estimates that home-based alternative tourism at the time accounted for about 15 per cent of all foreign stay over nights in Bulgaria, 9 per cent in Slovenia, 1 per cent in Mauritius and 0.1 per cent in India. Wall (1997a) describes the homestay sector as a significant indigenous initiative that included over 1600 available rooms in the early 1990s. One of the most widely cited examples of pioneering alternative tourism, though not strictly home based, is the cultural villages of the Casamance region in southern Senegal, which were established beginning in the mid - 1970s and accommodated 20,000 visitors in 1990 (Echtner, 1999; in Weaver, 2006, p. 39).

In order to know about homestay, first and fore-most it is important to know what the home represents. Rybczynski(1998; in Lynch and MacWhannell, 2000, p.103) identifies the meaning of home as bringing together the meanings of house and of household, of dwelling and of refuge, of ownership and of affection. 'Home' meant the house, but also everything that was in it and around it, as well as the people, and the sense of satisfaction and contentment that all these conveyed. Thus, home has multiple meanings, and operates on different levels both simultaneously and for individuals. Adding commercialized hospitality to the equation further complicates the dimension of the home and its meanings.

'Home' as an idea is not a simple concept but one which has multiple meanings and significance: worksite, memories and associations, place to rear family, a refuge, prison, statement of independence; ideas of security, affection and comfort (Franklin, 1986; in Lynch and Mac Whannell, 2000, p. 103); a place of self-expression, a cocoon, a place of deep contentment in the innermost temple of the soul (Lynch, 2003); a relatively recent term of nostalgia (Lynch and MacWhannell, 2000, p.103); associated with comfort, domesticity; a place under feminine control; place of ritual and customs (Telfer, 1995; Rybczynski, 1988); site of patriarchal relations. In this study, the home is connected with a small accommodation business to which Lynch (2000) has coined the term as "home-stay" and "commercial home" enterprise (McIntosh et al., 2010, p. 3). 
According to Lynch (2005b, p.534; in McIntosh et al., 2010, p.3), “ Commercial home" refers to types of accommodation where visitors or guests pay to stay in private homes, where interaction takes place with a host and/or family usually living upon the premises and with whom public space is, to a degree, shared. "Commercial home" therefore embraces a range of accommodation types including some (small) hotels, bed and breakfasts....., and host family accommodation, which simultaneously span private, commercial and social settings".

In the context of Nepal, Sedai (2011, p. 112) writes, "home-stay tourism is a community based programme introduced by the Government of Nepal (GoN) to provide accommodation facilities for tourists. In this programme, villagers host visiting tourists, and provide them food and accommodation facilities as a paying guest and in a completely homely environment." In Nepal the concept of home-stay was introduced to address the accommodation problems of ecotourism (Thapaliya et.al., 2012, p. 105). Therefore, home-stays are available on rural areas. Home-stay tourism in fact can promote ethnic tourism because there will be direct host-guest interaction and tourists can directly experience the cultural life of a community. For those tourists interested in ethnic tourism, this can be a beautiful experience. However, as of now home-stay tourism has not been advocated strongly as a way to bolster up ethnic tourism.

There are 297 home-stays developed in eight various rural villages in Nepal (NTB/CEST, 2010). This includes Sirubari (Syangja district), Gurung Heritage Trail (GhalegaunPasgaun-Nagidhar), Barapak homestay (Gorkha), Tamang Heritage Trail (Rasuwa), Indigeneous Peoples Trail (Ramechhap), Numbur Cheese Circuit (Ramechhap), Shree Antu (Ilam) and Olangchula Gola (Taplejung). These home-stays provide 1020 tourist beds in total. Among these, Shree Antu has the highest number of tourist beds, 403 tourist beds, whereas Olangchula Gola provides only 12 tourist beds (NTB/CEST, 2010).

\section{Amenities}

The introduction of TRPAP developed the necessary infrastructure, acknowledged for its transparency and rural development interventions. These include small-scale tourism infrastructure such as the construction of trails, bridges, signposts, information centres, public (porter) shelters, improved water, sanitation and waste disposal. The village holds continuous supply of electricity from Chilime Hydropower, telephone lines and community taps. The groceries are tourist friendly; sanitizer, toiletries, chocolates, energy drinks and soft drinks are available according to the tourist comfort. The daily goods are available in local groceries whereas huge volume are bought from Syabrubeshi and Betrabeti. The hot and cold bucket shower is yet another experience amidst the authentic experiences. The 4 homestays, 1 lodge and one community lodge give the unique cultural experience to the tourists with variety of food choices, local wine tasting, cultural dances, folk songs and many more. The effective host-guest interaction gives the tourist good sense of authentication despite the different mode of communication whether using pen, pencils or some communicative languages. 


\section{Community's Perception of Tourism}

Tourism brings several benefits to the host community. With the concept of propoor development and poverty alleviation through rural tourism, TRPAP provided training of various areas such as basic hospitality and English language, small hotel and lodge management, food and beverage services, cookery and bakery, eco-tourism, local tour guide, basic english language, home-stay management, professional trekking guide, tourism enterprise development, management capacity enhancement and general awareness training for porters.

TRPAP successfully encouraged local cultural . It has helped to revive the local culture, which was at the verge of extinction. Local groups, the majority of whom are women, have successfully adapted their cultural programs for commercial use, performing for guests at a reasonable cost.The Community Lodge and Cultural Centre was developed with the villagers so they can engage with commercial activities. The Tamangs of Gatlang are now aware of the benefits of tourism. Tourism has not only enhanced their economy but also provided them sense of ownership and pride(Dhakal, 2011).

People believe that tourism has enhanced livelihood, increased employment, created awareness, local resources, promoted culture, upgraded lifestyle, increased health and sanitation possibilities to meet the need of tourists.

Tourism in Gatlang has strong multiplier effect to the rural livelihood of the community. The study findings indicate that $31 \%$ respondents perceived the benefit of tourism for education sector. Likewise, 57 percent respondents perceived the benefits for agriculture sector, 31 percent for livestock and 78 percent for general business such as home stays, lodges and groceries.

Table-4: Distribution of respondents by multiplier effects of tourism in other sectors

\begin{tabular}{|l|c|c|}
\hline Perception & Number of Respondents & Percentage \\
\hline Education Sector & 22 & 31 \\
\hline Agriculture Sector & 41 & 57 \\
\hline Livestock & 31 & 43 \\
\hline General Business & 56 & 78 \\
\hline
\end{tabular}

The research finding revealed that the community is happy with benefits from the tourism. Majority of those (61 per cent) says that community are getting much benefits as many of them own a home stay or lodge. Further, much people are aware of the benefits from tourism as they are invited to perform cultural dances and get to sell their products. Very few respondents (8 percent) view tourism as least beneficial. The reason for such can be attributed to either ignorance or unaware of tourism due to their old age. 
Table-5: Distribution of respondents by the degree of benefits achieved from tourism

\begin{tabular}{|l|c|c|}
\hline Perception & Number & Percentage \\
\hline Very Beneficial & 20 & 61 \\
\hline Normal & 10 & 31 \\
\hline Very Little & 2 & 8 \\
\hline None & 0 & 0 \\
\hline Total & $\mathbf{3 3}$ & $\mathbf{1 0 0}$ \\
\hline
\end{tabular}

Tourism in Gatlang has benefiting rural poor community through the infrastructure development. The majority of the community household perceived that tourism has helped bringing community infrastructure. Tourism has helped bring much on community infrastructure such as roads, trail, bridge, community taps, electricity, telephone, resting places, sign posts and so on.

The local people has promoted their traditional dress (women), traditional domestic archives, traditional agriculture, water mills as major cultural attractions. This living culture has been portrayed as cultural involution by the villagers. In addition, the changing culture is presented to the tourists. The modification of the dances and songs to comfort tourists are presented as model culture.

\section{Tourist's Perception about Gatlang}

The maximum number of tourists visited Gatlang for wilderness trekking. Also they are cultural and natural trekkers. Again the ethnicity/culture and heritage attracted tourist as motivational factor and many tourists have regarded Gatlang as a treasure of Tamang Heritage Trail but at the same time, discourage the cultural change in the community through tourism and favors cultural involution instead. They prefer homestays as authentic cultural experience and hospitable than lodges.

\section{Tourist's Perception of Individual Attractiveness in Gatlang}

To identify the attractiveness of individual tourism resources, visitors were requested to assign the value i.e. 3 for strong, 2 for medium and 1 for low for the individual attraction/resources.

Table-6: Distribution of tourists by the weightage of various Touristic Attraction

\begin{tabular}{|l|c|c|c|c|c|}
\hline Perception & $\begin{array}{c}\text { Strong } \\
(\mathbf{3})\end{array}$ & $\begin{array}{c}\text { Moderate } \\
(\mathbf{2})\end{array}$ & $\begin{array}{c}\text { Low } \\
(\mathbf{1})\end{array}$ & $\begin{array}{c}\text { Total } \\
\text { Weightage }\end{array}$ & $\begin{array}{c}\text { Attractiveness } \\
\text { Position }\end{array}$ \\
\hline $\begin{array}{l}\text { Tamang culture, } \\
\text { tradition and customs }\end{array}$ & 15 & 12 & 3 & 72 & $1^{\text {st }}$ \\
\hline $\begin{array}{l}\text { Tamang settlements } \\
\text { and Architect }\end{array}$ & 11 & 17 & 2 & 69 & $2^{\text {nd }}$ \\
\hline
\end{tabular}




\begin{tabular}{|l|c|c|c|c|c|}
\hline Perception & $\begin{array}{c}\text { Strong } \\
(\mathbf{3})\end{array}$ & $\begin{array}{c}\text { Moderate } \\
(\mathbf{2})\end{array}$ & $\begin{array}{c}\text { Low } \\
\mathbf{( 1 )}\end{array}$ & $\begin{array}{c}\text { Total } \\
\text { Weightage }\end{array}$ & $\begin{array}{c}\text { Attractiveness } \\
\text { Position }\end{array}$ \\
\hline $\begin{array}{l}\text { Surrounding Mountains } \\
\text { and Landscape }\end{array}$ & 13 & 12 & 5 & 68 & $3^{\text {rd }}$ \\
\hline Nearby spots & 11 & 13 & 6 & 65 & $4^{\text {th }}$ \\
\hline Forest & 9 & 11 & 10 & 59 & $5^{\text {th }}$ \\
\hline
\end{tabular}

The research data indicated that Tamang culture, tradition and customs stands for the first position with the weightage value (72) followed by Tamang settlements and architect (69), surrounding mountains and landscape (68), hot spring (68) and the forest and wildlife (59) as second, third, fourth and fifth position respectively. From above findings, the major tourism activities in the THT can be elaborated as cultural study, village walk, observation of live craftsmanship and old aged architectures, cultural performance and wilderness trekking.

\section{Hospitality Facilities in Gatlang}

The hospitality of host was also studied with the tourists interviews .57 percent visitors perceived that the host community were very hospitable, followed by 36 percent community who perceived the hospitality as just hospitable and 7 percent rated the hospitality as poor.

Table-7: Distribution of tourists by the rating of Hospitality

\begin{tabular}{|l|c|c|}
\hline Perception & Number & Percentage \\
\hline Very hospitable & 20 & 57 \\
\hline Hospitable & 8 & 36 \\
\hline Poorly hospitable & 2 & 7 \\
\hline Total & $\mathbf{3 0}$ & $\mathbf{1 0 0}$ \\
\hline
\end{tabular}

\section{Visitors Perception on Modes of Accommodation}

Community lodge, home stay and normal hotel/lodge offer accommodation facilities at Gatlang. Research findingrevealed that majority of the trekkers (70 percent) use local hotel and Home-stay.Some group trekker use (23 percent) tented camping. About 7 percent trekkers use a combination of both the facilities.

Table-8: Distribution of tourists by the use of modes of accommodation

\begin{tabular}{|l|c|c|}
\hline Modes of accommodation & Number & Percentage \\
\hline Local hotel, lodge, Home-stay & 21 & 70 \\
\hline Tented camp & 7 & 23 \\
\hline Both & 2 & 7 \\
\hline Total & $\mathbf{3 0}$ & $\mathbf{1 0 0}$ \\
\hline
\end{tabular}


While asking the visitors for their perception on the condition of accommodation facilities, the Home-stay and community lodge was perceived as good and sufficient for accommodation. Most (70 percent) of the visitors perceived hotel/lodge facilities as fair. The tea house and camping site facilities was perceived as the poor and insufficient by the respondents respectively.

Also, the visitors are surprised by the availability of choices in food of their preference like porridge, cornflakes, chocolates. However, the taste of food did not meet the visitors' expectation. But the local wine was highly demanded and they enjoyed local wine tasting with great excitement. The groceries were satisfactory according to the visitors.

Table-9: Distribution of tourists by the rating of infrastructures

\begin{tabular}{|l|c|c|c|c|}
\hline Infrastructure & Sufficient & Moderate & Poor & Total \\
\hline Telecommunication & 5 & 12 & 13 & 30 \\
\hline Trails & 25 & 3 & 2 & 30 \\
\hline Road & 0 & 28 & 2 & 30 \\
\hline Resting places & 20 & 7 & 3 & 30 \\
\hline Drinking water & 10 & 13 & 7 & 30 \\
\hline Electricity & 20 & 5 & 5 & 30 \\
\hline Sanitation & 5 & 5 & 20 & 30 \\
\hline
\end{tabular}

The data indicated that the infrastructure is not so well developed in Gatlang. However, the resting places, drinking water and electricity are satisfactory. The tourist can get hot drinking water if they ask around the route and their stay. However, some nominal price is charged for the water. The sanitation is very poor even with the availability of separate toilets in every house. Most of the tourists are satisfied with the trails. The resting places are also appreciated whereas tourists are unsatisfied with the sanitation scenario of the village.

\section{Overall Satisfaction Level}

The overall experiences of the visitors stand the THT as a potential tourist destination. Of the total visitors, 37 percent concluded the visits as very satisfactory followed by 63 percent visitors who concluded the visit as satisfactory.

\section{Economic Impact of Tourism in Gatlang}

Tourism is genuinely powerful and unique force for the change in community. According to statistics of tourism 803,092 tourists visited Nepal collecting NRs 30,725,870 revenue in the year 2012.Ethnic tourism supports the tourists stay in natives and observe day to day life from dawn to dusk, family, marriage, religion, festivals, dressing patterns, life cycle ceremony, culture and so on. Although Trishuli Somdang highway linked the villages more than two decades ago and tourists started to come to Langtang on trekking, 
residents of northern parts of Rasuwa had not seen any change in their livelihood. Surviving on a subsistence-based farming and living in most unhygienic place, their per capita is among the lowest in the region. According to District Development Committee Rasuwa, four northern remote villages Gatlang, Goljung, Chillime, Briddim and Thuman are most underdeveloped parts of the district. However the program contributed to the poverty alleviation objective of the government through review and formulation of policy and strategic planning for sustainable tourism development that are pro-poor, pro-environment and pro rural communities and pro-women and enhance the livelihood of the people with tourism as income generating activities.

The geographic setting (habitat), the heritage(monasteries, chortens, manis, architecture), the effects of acculturation(history and change) and the inexpensive souvenirs are the cultural attractions of Gatlang.

With the technical and financial support granted from DFID, UNDP, SNV-Nepal through TRPAP, DDC Rasuwa has been able to efficiently implement the rural tourism programme in the northern part of the district. A new tourism product called Tamang Heritage Trail has been developed and promoted comprising the settlement of the poor people in Gatlang, Chillime and Goljung area.

TRPAP has tremendously changed the life of local people of The Tamang Heritage Trail. The opening of the closed route has given many fruitful exposure to the locals. TRPAP not only opened the route but also opened the path to connect the rural people with the outer world. The people otherwise would have been backward in every aspect of infrastructure and opportunities. It initiated to run roads to the village from Syabrubeshi to Gatlang which in resulted in alternative livelihoods capacity building, skills training, increased agricultural productivity, employment opportunities, empowerment, and the improved ability to combat poverty.The initiative through Venture Capital Fund (VCF) of TRPAP provided soft loan to the locals along with the trainings. The interested people were given the trainings of guide, porters, and cooks to combat poverty and enhance their livelihood. The women were given training to weave the woolen products and the pricing of the products. The free time is thus utilized as knitting and making many woolen products. TRPAP opened community lodge and encouraged many to open home stays. The establishment of toilets, water supply have helped a lot in sanitation however the sanitation is not that good. The sign posts, public shelters are of great help to the tourists.

The TRPAP VCF has overcome these constraints by making soft loans with simple procedural formalities available to the rural poor to start small enterprises. This initiative has helped people to continue their traditional source of income through animal husbandry in Gatlang. Many have added the number of chauris, goats, oxen through the soft loans from TRPAP. This pioneering model has shown positive results. (See detail in appendix 1) 
The GLCC, built with TRPAP support, is a wonderful structure in terms of design and architecture. It has separate dormitory-type accommodation for men and women, a dining room, solar-heated showers, toilets and an incinerator for waste disposal. It has a beautiful courtyard in the front for open-air cultural performances. A spacious hall on the ground floor can be used for indoor cultural shows, meetings and exhibitions. The Lodge and Centre is developed and managed by the Sustainable Tourism Development Committee( STDC). The committee has deputed a young woman and boy to look after visiting tourists. They are very courteous. The woman says: "I am not only getting economic benefits, but I'm also developing cooking and hospitality skills from the training and practical work at the Centre."

Once locals are confident enough to develop home-stay or lodges in the villages, the Centre will be converted into a Tamang Museum and Cultural Centre.A local villager happily admits: "Due to the accommodation facility developed in the village, tourists have begun to arrive. It has given us much benefit to sell chicken and vegetables to the Lodge." In Rasuwa, the project has brought not only infrastructures but the project also contributed to develop Tamang Cultural Heritage Trail as a new tourism product which has all components to attract tourists and extremely helpful to generate income with local ownership and benefit sharing.

\section{Socio- Cultural impact of tourism in Gatlang}

It is very difficult to assess socio-cultural impacts. The influences are not always apparent, as they are often indirect, hard to measure, ambiguous and dependent on value judgments. Not only tourists, but also local people who travel for education, trade or other purposes bring in new ideas and behavior that affect cultural practices. The world is now connected together through media and information technology. Often, socio-cultural impacts are hard to disentangle from wider processes of development (also Ashley, 2000), or globalization (Blench, 2001; DFID 1999). The Tamangs of Gatlang, for instance, have not only become more affluent, but also more westernized after tourism has taken off in their areas. Tamang culture has undergone many undesirable transformations - for instance neglecting their traditional agricultural and pastoral activities, which always formed the basis of their traditional culture, and sending less lamas to their monasteries, withdrawal. of the use of their traditional dress, linguistic acculturation and so on.

Many cases of cultural involution and changing culture were noted by the researcher. On the one hand, the women and older generation people emphasize on cultural involution through their traditional dress, traditional farming, traditional life style and traditional weaving in Taan to provide extremely authentic cultural experience to the tourists through living culture. On the other hand, due to the incidence of commoditization as changing culture, they showcase the performances as per the nature of tourists as a model culture. The dances and songs are modified to attract tourists and the tourists enjoy the front stage authenticity without taking back stage 
authenticity into consideration. The shoes used in dances are not traditional, the main instruments tungana is not played. The model culture as mentioned by Smith(1989) to maximise the benefits of tourism are also adopted by the natives. This has promoted the commoditization of the cultural products of Gatlang. The proper balance between the authenticity and commoditization may however result in the increment of tourism. However, the marketing of the tourism products has increased the public awareness about the importance of ethnicity as a tool for resource conservation and cultural preservation through ethnic tourism.

Also the power relation between the people in the communities have changed a lot after the incidence of tourism. The class difference is emerging with rich getting richer through home stays and lodges and poor the poorer. This has slowly fueled the latent conflict within the community. However, the community lodge has somehow helped to minimize this risk through the benefit sharing (income is used to promote culture and other activities within community)within the societies and promoting localization of the resources.

However, the Tamang themselves have heartily embraced these changes, feeling that the economic prosperity brought by tourism has directly helped to improve their general living standards and significantly improved their quality of life. Many changes are natural byproducts of development, in fact highly sought after by Tamang community.

\section{Tourism as a tool for socio-cultural conservation}

It is clear that tourism has contributed the promotion of development by providing for, and enhancing, for instance infrastructure, educational opportunities, water and electricity supply and health care provisions. It has functioned as a direct tool for the conservation of the rich cultural heritage of the Tamang people. Tourism has fostered pride in cultural traditions and provided Tamang people value (and income) to the maintenance and restoration of authentic cultural features, and support community development - for instance by helping to avoid urban relocation by creating local jobs. Studying the socio-cultural impacts of tourism in THT, tourism has led to a revitalization of the Tamang culture, as the international exposure of their culture after the scaling of The Tamang Heritage Trail(THT) has made them a 'celebrated people'.

\section{Tourism and acculturation}

The term 'acculturation' takes place in a complex and piecemeal fashion, and is more a matter of give-and-take between individual world-views. To take of the 'sociocultural changes' brought by tourism can be a shorthand only, part of a larger understanding of the way in which universally, people go and look beyond themselves in order to be and know themselves (Kunwar, 2002, p.72).Tourism is very much relatedwith clothing; the changes in clothing is highly visible as an influence of tourism 
in Gatlang. After the opening of closed route to Gatlang, the natives can easily get western clothes and footwears which they carry as status symbols. The nominal new patterns of food are visible but yet maximum population still prefer their traditional staple dhindo. The cross cultural communication is easy with the elementary English courses by TRPAP but resulted in the linguistic acculturation. The impacts on cultural environment: history with change in cultural landscape, language with change in vocabulary of languages(linguistics acculturation), food acculturation, dress acculturation, religion with decrease in the cultural practices with western influence of tourist, values and norms with change in family size and structure are visible in Gatlang.

Others, however, claim that tourism has had many negative impacts on the sociocultural environment of the mountain communities. The erosion of cultures and associated values such as the dissolution of distinctive cultural attributes and traditions (e.g. changes in people's behavior, dress and lifestyles), changes in family and social structures, pollution of sacred places and a breakdown in religious beliefs, and a loss of traditional community support systems were reported by the respondents. The tourists, mostly by the virtue of their purchasing power, may eventually destroy the very thing they came to visit, by transforming local cultures into commodities for sale, and changing sustainable lifestyles into an extractive and consumptive lifestyle (e.g. King and Steward 1996). However, it is arguable to what extend this is necessarily bad or threatening to the cultural heritage. Is it bad that a dance that is traditionally performed only during certain festivals are now staged several times per year, if this increases the pride in local cultural traditions and allows the people to gain a better living from it, and may bring cultural aspects to the forefront that otherwise might get lost or forgotten.Again, the pattern is dynamic and impacts are not necessarily stable or constant. However, tourism is frequently accused of destroying authenticity through commoditization of cultures, traditions, festivals, dance, rituals and food which is produced for monetary gain.

Negative impacts on culture generally manifest themselves early, but once communities start profiting from tourism they tend to place more effort on reviving the cultural characteristics that attract tourists in the first place. Similar is the scenario of Gatlang. People were unaware of the benefits of tourism earlier and were noncooperative but with time tourism benefitted $t$ and changed their lifestyle with provisions of infrastructures, and job creations. Now, the people highly appreciate tourism and its benefits with the sense of ownership.

\section{Tourism in Gender mainstreaming}

In Gatlang, the Tamang community, men traditionally worked as the head of the household; however, many have now become dependent on the income that women and young children earn. This new gender division of labor in the household income structure conflicts with patriarchal gender complementarity. Women are aware of the 
benefits of tourism and realise that their skills can be used to earn money by producing attractive souvenir items. With training and study visits, women have learned how to mobilise local resources for tourism, such as village visits, handicraft exhibitions and showing local culture to tourists. Women and the poor have been empowered through special awareness programmes, capacity building activities, and skill development and leadership training. Also the men of the family are busy with livestock. Due to the land topography, usually men live in the field with livestock during winter and during summer move to higher altitude. Hence, many decisions are taken by women to the tourists.This "contradiction" and "stigma for men" has led to alcohol and narcotic abuse among the community's men. According to the nesting double marginalization structure, the role of kin-based household economies to strengthen ethnic identity and gender roles are threatened.

Naturally, this is not to say that tourism development should take place without any regard for the socio-cultural environment, or that appropriate strategies can help mitigate unwanted impacts at least within the limits of acceptable change.

\section{Tourism Leakage}

The general perception among local is that the local economy is benefitted more by free individual travelers (FITs) as they consume local services, such as accommodation, whereas the organised troops bring their own supplies. These yields of substantial portion of income from tourism remain at the local level with the consumption of local foods and engagement of local people. However, in Gatlang the communities believe that tourists may not like to consume local food and they provide multiple choices of tourist-friendly food imported from Dhunche. This has resulted in the tourism leakage in Gatlang. But the visitors are encouraged to try local eggs, local wine and originally prepared alcohol(raksi, jaand). This has however helped to decrease the leakage of tourism expenditure in Gatlang to some extent.

\section{Tourism Safety and Security}

Safety and security are the major deciding factor of tourism. Tourist's behaviour and their visits are highly dependent on the management of safety, security and risk. However, the emergency service and rescue service is not managed. Though Gatlang is not that difficult grade of trekking but the mountains are steep as the trail furthers to Tatopani, Briddim and Timure. However, no case of emergency is noted till the date. Whereas Lantang Trek is regarded as one of the unsecured treks with many cases of disappearance and looted. Recently Banskota (2014) has exposed some 26 tourists visiting mountainous areas of Nepal are disappeared. Out of which 3 trekkers have been disappered in Langtang-Gosaikunda areas. In this regard, the police authority assumes that the reason of disappearance of the tourists is they do trek alone with no guides and therefore, they might have murdered because of having their belongings such as camera, mobile and cash along with them (see in detail Kunwar and Barmashkha, 
2014). So, the system should make strong strategies to combat these sorts of events and help to promote safe trekking and tourism. The entry point of tourists should maintain good and authentic records of the tourists arrival and exit. THT was found as the best model of rural tourism development to establish and set indicators of sustainability for tourism development in rural context of Nepal.

\section{Conclusion}

Tourist sites are seen not merely as stages where tourists perform, but as the physical platforms for collective reflection and articulation of group identities (Chronis, 2006, p. 267). Hence, Gatlang as tourist site reflects rich culture, ethnicity and traditional village. The village is cluster shaped with specific roof of wooden blocks and walls of stones. All the 402 houses look alike in structure with wooden carvings in windows and doors. The room structure of kitchen bedroom, family size, rites and rituals have helped a lot in attracting tourists. With the introduction different trainings by TRPAP Gatlang has created more job opportunities and happy families. The strength of tourism attraction in Rasuwa was found very strong. Tamang Culture was found as the prime tourism product complimented by the natural and historical attraction as an ancillary products. The research findings indicated the blend of cultural experiences and nature trekking as the composite motivation factor for the visitors. Majority of the visitors have rated THT as strongly potential destination along with unspoiled Tamang culture .

Tamang culture, tradition and customs have been rated as the prime attraction through the homestay in Gatlang. The tourists choose their stay in homestay for authentic experience from dawn to dusk. This has encouraged the locals to preserve their culture along with the monetary gain from the tourists. The presence of flora and fauna, an important motivation for the general trekkers in Nepal, seems relatively poor in THT. Besides strong tourism resources and hospitable people, the demands for Gatlang Trekking was constrained by the insufficient information, accommodation and infrastructure, rescue/emergency facilities. The social incentive in the form of grant for tourism infrastructure development, skill development training, flow of soft interest loan as venture capital fund (VCF), promotional support are found very strong in THT. It lacks proper zonation of area and analysis of carrying capacity for the sustainable use of resources and greater satisfaction of the visitors. The use of improved sanitation, toilet and improved energy devices by general people (besides tourist business people) is very lower.

THT was found as the best model of rural tourism development to establish and set indicators of sustainability for tourism development in rural context of Nepal. Various cases of cultural involution and changing culture based issues have been concluded and established from the study.The place marketing is highly valuable in promoting any destination. Local tourism institutions have been involving in the planning and development of tourism activities through participatory approach. Still, 
the present resources and confidence level of those institutions seems relatively lower to continue the efforts. Management and control mechanism was found relatively very poor. Nevertheless, it deserves high level of control mechanism for the participation of women and poor and participatory decision making. With the concept of place marketing and SWOT analysis, Gatlang can claim itself to stand tall among all the other touristic destinations. The collaborative efforts from local,public and private sectors can promote ethnic tourism in Gatlang to great extent.

\section{References}

Banskota, P. (2014). Dui Barshama 26 Paryatak Haraye. Kantipur (Nepali Daily Newspaper), June 5.

Bezruchka, S. (2001). Trekking in Nepal, 7th Edition, Kathmandu: Mandala Book Point.

Belhassen, Y., Caton, K. and Stewart, W. P. (2008). The Search for Authenticity in the Pilgrim Experience. Annals of Tourism Research, 35(3), pp.668-689.

Berghe, P. L. (1995). Marketing Mayas: Ethnic Tourism Promotion in Mexico. Annals of Tourism Research, 22(3), pp.568-588.

Berghe, P. L. (1992). Tourism and the Ethnic Division of Labor. Annals of Tourism Research, 19(2), pp.234-249.

Boorstin, D.J. (1964). The Image: A Guide to Pseudo-Events in America, New York: Harper and Row.

Bruner, E.M. (2005). Culture on Tour, Chicago: University of Chicago Press.

Butler, R. and Hinch,T. (2007). Tourism and Indigenous Peoples. Amsterdam: Elsevier.

Cheung, S.C.H. (1999). The Meanings of the Heritage Trail in Hong Kong, Annals of Tourism Research, 26 (3),pp. 570-588.

Chronis, A.(2006). Heritage of the senses. Tourist Studies, 6(3), pp. 267-296.

Cohen, E. (1974). Who is a Tourist? Sociological Review, 22 (4), pp. 527-553. (1988). Authenticity and Commoditization in Tourism. Annals of Tourism Research, 15, pp.371-386.

Graburn, N.H.H. (1976). Ethnic and Tourist Arts Cultural Expression from the Fourth World. London: University of California Press.

London: Routledge. (2000). Commoditisation. In Jafari, J. (ed.) Encyclopedia of Tourism,

Greenwood, D.J. (1989). Culture by the Pound: An Anthropological Perspective on Tourism as Cultural Commoditization. In Smith, V.L. (ed.) Hosts and Guests: The Anthropology of Tourism (pp. 171-185), Philadelphia: University of Pennsylvania Press. 
Gru "newald, R. A. (2002). Tourism and Cultural Revival. Annals of Tourism Research, 29(4), 1004-1021.

Hall, C. Michael. (2007). Response to Yeoman : The Fakery of 'The authentic tourist'. Tourism Management, 28(3), pp.1139-1140.

Harkin, Michael. (1995). Modernist anthropology and tourism of the authentic. Annals of Tourism Research, 22(3), pp.650-670

Harron, S. \& Weiler, B. (1992). Review. Ethnic Tourism. In Wailer B. and Hall, C. M. (eds.) Special Interest Tourism (pp. 83-92), London: Belhaven.

Hinch, T. and Butler, R. (1996). Indigenous Tourism: a Common Ground for Discussion. In Hinch, T. and Butler, R. (eds.), Tourism and Indigenous Peoples. London: International Thomson Business Press.

Holmberg. D. H. (1996). Order In Paradox Myths, Ritual and Exchange among Nepali Tamang. Delhi: Motilal Banarasidas Publishers.

Ishi, K. (2012). The Impact of Ethnic Tourism on Hill Tribes In Thailand. Annals of Tourism Research, 39 (1), pp. 290-3010.

Jamal, T., Everett, J. and Dann, G.M.S.(2003). Ecological Rationalization and performative resistance in natural area destinations.Tourist Studies, 3(2), pp.143169.

Kane, M. J. and Tucker, H. (2004). Adventure Tourism. Tourist Studies, 4(3), pp. 217 234.

King,T.F.(2011). Introduction. In King, T.F.(ed.) Praise for A Companion to Cultural Resource Management (pp. 1-10) Oxford: Wiley- Blackwell.

Knudsen, D.C., Soper, A.K. and Metro-Roland, M.M. (2008). Landscape, Tourism, and Meaning: An Introduction. In Knudsen, D.C., Soper, A.K. and Metro-Roland, M.M. (eds.) Landscape, Tourism, and Meaning (pp.1-7), Aldershot:Ashgate.

Kunwar, R.R. (2002). Anthropology of Tourism A Case Study of Chitwan Sauraha, Nepal, Delhi: Adroit Publishers.

(2013). Sport Tourism: Understanding the Concept, Recognizing the Value. Journal of Tourism and Hospitality, 5 pp. 13-42.

(2012). Safety and Security in Tourism: A Study of Crisis and Disaster Management. Journal of Tourism and Hospitality Education, 2, pp.58-83 (2010). Tourists and Tourism: Science And Industry Interface. Kathmandu: Ganga Sen Kunwar.

(2002). Anthropology of Tourism: A Case Study of Chitwan, Sauraha. Delhi: ADROIT Publishers.

(1996). Ethnicity in South Asia. Kathmandu: Laxmi Kunwar 
Kunwar, R.R. and Barmashkha, S.(2014). Tourism and Crime: A Case Study of Nepal. Journal of Tourism and Hospitality Education, 4, pp.1-22.

Kunwar, R.R. and Ghimire, H.L.(2012). Lumbini as International Pilgrimage Destination: Authenticity and Significance. The Gaze: Journal of Tourism and Hospitality, 4 (1), pp.1-33

Lynch,P. And MacWhannell,D.(2000). Home and commercialized hospitality. In In Search of Hospitality:Theoretical Perspectives and Debates(pp. 100-114). Oxford:Butterworth-Heinemann.

MacCannell, D. (1984). Reconstructed Ethnicity:Tourism and Cultural Identity in Third World Communities. Annals of Tourism Research, 11,pp. 375-391. (1973). Staged Authenticity arrangements of Social Space in Tourist Settings. American Journal of Sociology, 79(3),pp. 589-603.

- - _- - (1976). The Tourist: A New Theory of Leisure Class, London: Macmillan. (1992). Empty Meeting Grounds: The Tourist Papers, London and New York: Routledge.

Mckean, P. F. (1989). Towards a Theoretical Analysis of Tourism: Economic Dualism and Cultural Involution in Bali. In Smith, V.L. (ed.) Hosts and Guests: The Anthropology of Tourism (pp. 119-138), Philadelphia: University of Pennsylvania Press.

March, K. (1987). Hospitality, Women and the Efficacy of Beer. Food and Foodways, 1, pp. 351-387.

Mathieson, A and Wall, G. (1982). Tourism: Economic, Physical, and Social Impacts, Singapore: Longman Publishers.

Mayhew, B. and Bindloss, J. (2009). Trekking in the Nepal Himalaya. Lonely Planet

McIntosh, A.J. , Lynch , P. and Sweeney, M.(2010). My Home is My Castle: Defiance of the commercial homestay host in tourism. Journal of Travel Research. XX(X),pp. $1-11$.

Ministry of Culture, Tourism and Civil Aviation (MOCTCA). (2013). Nepal Tourism Statistics 2012. Kathmandu: MOCTCA, Government of Nepal

Morse-Kahn, D.(2011). History as a Cultural Resource. In King, T.F.(ed.) Praise for A Companion to Cultural Resource Management (pp. 128-140) Oxford: WileyBlackwell.

Nash, D.( 1996). Anthropology of Tourism. New York: Pergamon.

NTB/CEST Nepal .(2010). An Inventory of formal accommodation facilities in the major selected tourist areas of Nepal. Kathmandu:Nepal Tourism Board and Centre for Environment and Sustainable Tourism Development Nepal. 
Odell, M. J. and Lama, W.B. (1998). Tea House Trekking in Nepal The Case for Environmentally Friendly Indiginous Tourism. In East, P., Luger, K. and Inmann, (eds.) Sustainability in Mountain Tourism (pp. 213-222), Delhi: Book Faith India \& Studenverlag/Innsbruck-Vienna.

Ojeda, N. (1996). Ethnic Tourism: The Case of Cuetzalan, Mexico.

Pandey, R.J. (2009). Community Based Pro-Poor Tourism: Lessons from TRPAP. In Kruk, E., Kreutzmann, H. and Richter, J. (eds.) bIntegrated Tourism Concepts to Contribute to Sustainable Mountain Tourism.pp. Kathmandu, giz, icimod, bmz. 960112.

Pandey,R.J.(2003). Challenges in Managing Community based Ecotourism Projects: A Case of TRPAP. Paper presented at the $4^{\text {th }}$ Asia Pacific Ecotourism Conference (APECO), Malaysia.

Park, H.Y.(2014). Heritage Tourism, London: Rouledge.

Patullo, P. (2006). Reclaiming the Heritage Trail: Culture and Identity. In France, L. (ed.) Sustainable Tourism (pp.135-148) First South Indian Edition, New Delhi: Viva Books.

Picard, M. (1993). Cultural Tourism in Bali: National Integration and Regional Differentiation. In Hitchcock, M. King, V. and Parnwell, M. (eds.) Tourism in Southeast Asia (pp. 71-98), London and New York: Routledge.

Picard, M. and Wood, R. E. (1997). Tourism, ethnicity, and the State in Asian and Pacific societies. Honolulu: University of Hawai Press.

Reisinger, Y. and Steiner, C. J. (2006). Reconceptualizing Object Authenticity. Annals of Tourism Research, 33(1),pp. 65-86.

Sedai, R. C. (2011). Tourist Accommodation Facilities in the Major Tourist Areas of Nepal. Nepal Tourism and Development Review, 1(1), 102-123

Shaw, G. and Williams, A. M. (2004). Tourism and Tourism Space. London:SAGE. Smith, M. K. ( 2009). Issues in Global Cultural Tourism Studies. London: Routledge . (2003). Issues in Cultural Tourism Studies. London: Routledge .

Smith, V. L. (1989). Hosts and Guests, the Anthropology of Tourism. Philadelphia: University of Pennsylvania Press.

Smith, M. Macleod, N. and Hart Robertson,M. (2010). Key Concepts in Tourist Studies, London : Sage.

Stanton, M.E. (1989). The Polynesian Cultural Center. Multi-Ethnic Model of Seven Pacific Cultures. In Smith, V.L. (ed.) Hosts and Guests: The Anthropology of Tourism (pp. 247-262), Philadelphia: University of Pennsylvania Press.

Stronza, A. (2001). Anthropology of Tourism: Forging New Ground for Ecotourism and Other Alternatives. Annual Review of Anthropology, 30, pp. 261-283. 
Swain, M. B. (1993). Women producers of Ethnic Arts. Annals of Tourism Research, 20, pp.32-51.

Swarbrooke, J.B., Beard, C., Leckie, S. and Pomfret, G. (2003). Adventure Tourism The New Frontier, London: Butterworth/Heinemann.

Thapaliya, M., Rai, G.S., Shrestha, A., Parajuli, B. and Pande, O. (2012). Home-stay: Assessment in Lwang Ghalel. Nepal Tourism and Development Review, 2, pp. 105-140.

Thapa K., (2014). Langtang Nikunjaka Hotel Tenderbata Sanchalan Garine. Kantipur (Daily Nepali Newspaper), 18 April, p. 16.

Theobald, W. F. (1998). The Meaning, Scope and Measurement of Travel and Tourism. In Theobald, W.F. (ed.). Global Tourism: The Next Decade. London: ButterworthHeinemann.

Timothy, D.J. and Nyaupane, G. (2009). Introduction: Heritage Tourism and the Lessdeveloped World. In Timothy, D.J. and Nyaupane, G. (eds.) Cultural Heritage and Tourism in the Developing World (pp.1-17).

TRPAP. (2006). Case Study TRPAP: APPA Framework in Practice. Kathmandu: TRPAP. TRPAP. (2005). Tourism ResourceMapping Profile: Rasuwa District.Kathmandu: TRPAP.

TRPAP. (2007a). Lessons Learned: Nepal's Experience Implementing Sustainable Rural Tourism Development Model. Kathmandu: TRPAP.

(2007b). Pro-poor rural tourism initiatives and its sustainability in Nepal. Kathmandu: TRPAP

Urry, J. (2006). Preface: Places and Performances. In C.Minca and T. Oakes. (eds.) Travels in Paradox. Oxford: Rowman and Littlefield.

(2002). The Toursit Gaze. New Delhi: Sage.

UNESCO. (1995). Case study on the effects of tourism on culture and the environment Thailand, Thailand.

Van den Berghe, P. \& Keyes, C. (1994). Introduction: Tourism and Re-created Ethnicity. Annals of TourismResearch, 11, pp. 343-352.

Van den Berghe, P. L. (1992). Tourism and the ethnic division of labor. Annals of Tourism Research, 19, pp. 234-249.

(1994). The quest for the other: Ethnic tourism in San Cristobal. Mexico, Seattle \& London: University of Washington Press.

Wang, N. (1999). Rethinking authenticity in tourism experience, Annals of Tourism Research, 26(2), pp.349-370.

Wang, X. (2001). Cultural Tourism: An Assessment of Marketing Strategies In Dalian, Nanjing and Hainan, China, University of Alberta. 
Weiler, B. and Colin, M. H. (1984).Ethnic Tourism, the State and Cultural Change in Southeast Africa. Annals of Tourism Research,11(3), pp.353-374.

Weaver, D. (2006). Sustainable Tourism, Amsterdam: Elsevier.

Wethey, E. (2005). Creative Commodification of Handicrafts, the Encounter between the Export Market and the Indigenous Weaver: Comparisons of Latin American Weaving Communities. Lambda Alpha Journal, 35, pp. 2-27.

Willow, A.J.(2011). Culturally significant Natural Resources: where Nature and culture.Meet.In King, T.F. (ed.) Praise for A Companion to Cultural Resource Management, Oxford:Wiley-Blackwell (pp.114-127)

Winthrop, R. (1991). Dictionary of concepts in cultural anthropology. Westport, CT: Greenwood Press.

Wood, R.E. (1984). Ethnic Tourism, the State, and Cultural Change in Southeast Asia. Annals of Tourism Research, 11, pp. 353-374.

Xie, P. F. (2001). Authenticating Cultural Tourism: Folk Village in Hainan, China (Doctoral Dissertation). University of Waterloo. 